\title{
STIMULANT ACTION OF METHOXAMINE IN THE ISOLATED ATRIA OF NORMAL AND 6-PROPYL-2-THIOURACIL-FED RATS
}

\author{
Mitsuyoshi NAKASHIMA, Hiromichi TSURU and Tatsuro SHIGEI \\ Department of Pharmacology, Nagoya University School of Medicine, \\ Showa-ku, Nagoya, Japan \\ Accepted October 27, 1972
}

\begin{abstract}
Methoxamine showed positive inotropic and chronotropic actions in the rat atria. These actions were blocked by phentolamine, but not by propranolol. PTU treatment sensitized the animals to the positive inotropic and chronotropic actions of methoxamine. These results verify the findings of previous research that there are $\alpha$ adrenergic receptors in rat atria, that stimulation of these receptors shows positive inotropic and chronotropic action and that $\alpha$ receptors are sensitized by PTU treatment.
\end{abstract}

In previous papers from this laboratory $(1,2)$, it was reported that phenylephrine exerted positive inotropic and chronotropic actions on the isolated atria of 6-propyl-2thiouracil (PTU)-fed rats, mainly by stimulation of $\alpha$ receptors. This indicates $I$ ) involvement of the $\alpha$ receptor mechanism in the cardiostimulant action of catecholamines, and 2) exaggeration in the hypothyroid status. To further confirm these idcas, the present experiment was conducted with methoxamine which has a pure $\alpha$ stimulant activity.

\section{METIIODS}

Male Wistar rats ( 170 to $200 \mathrm{~g}$ ) were used. The rats were divided into two groups. One group was fed a normal diet while the other group was placed in a hypothyroid state following of $0.15 \%$ PTU diet for 6 to $8 \mathrm{wk}$. This group developed dry fur, slow heart rate and a considerable growth retardation.

Each rat was sacrificed by stunning. The excised, isolated left atrium was secured to a hook in a bath and suspended from a force displacement transducer (Nihon Kohden SB-1T). A resting tension of $0.5 \mathrm{~g}$ was placed on each atrium. The preparation was stimulated by a unipolar electrode ( $150 / \mathrm{min}, 3 \mathrm{msec}$. duration, voltage twice threshold). The isometric tension was recorded by an ink writing oscillograph (Nihon Kohden WI130). The bath contained $25 \mathrm{ml}$ Ringer's solution of the following composition (mM): $\mathrm{NaCl} 148, \mathrm{KCl} 5.6, \mathrm{CaCl}_{2} 2.2, \mathrm{NaHCO}_{3} 15.0$ and glucose 5.6. The solution was maintained at a temp. of $30+0.5 \mathrm{C}$ and bubbled with $95 \% \mathrm{O}_{2}$ and $5 \% \mathrm{CO}_{2}$.

The spontaneously beating right atrium was connected via a thin thread, to a semiconductor strain gauge. The amplified input from the strain gauge was used to drive a tachometer (Nihon Kohden RT-2). The beating rate was continuously recorded on 
an ink writing oscillograph. Drugs were dissolved in $0.9 \%$ saline. Before the drugs were added to the bath, the preparation was washed several times and allowed to stabilize for approx. 30 min. Methoxamine hydrochloride (kindly provided by Nihon Shinyaku, Ltd.), phentolamine mesylate (Regitin, Ciba-Geigy) and DL-propranolol hydrochloride (Inderal, ICI) were used in the present study. Phentolamine or propranolol was allowed to interact with the tissue for $30 \mathrm{~min}$.

Results were analyzed statistically by Student's $t$ test.

\section{RESULTS}

In the present experiment, methoxamine showed positive inotropic and chronotropic actions in both non-treated and PTU-fed rats.

Fig. 1 shows dose response curves for the inotropic action of methoxamine on atria from non-treated and PTU-fed rats, which were obtained by the cumulative dose method. The magnitude of changes was expressed as percent change to the amplitude existing just prior to the addition of the drugs. The increases in contractile force produced by methoxamine in PTU-fed rats were greater than those obtained in non-treated rats. These positive inotropic actions of methoxamine were blocked by $3 \times 10^{-7} \mathrm{M}$ phentolamine both in nontreated rats (Fig. 2A) and in PTU-fed rats (Fig. 2B). The responses to methoxamine

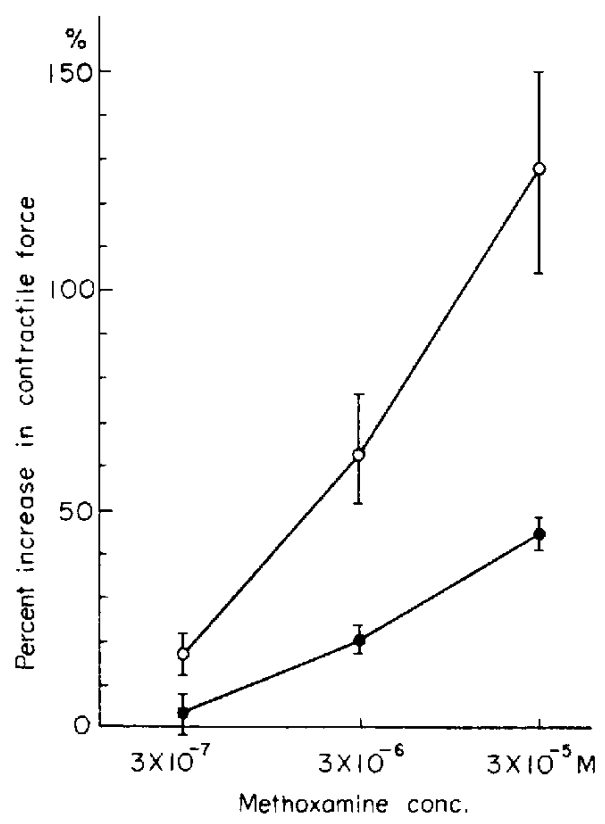

Fig. 1. Dose response curves for the inotropic action of methoxamine on atria from non-treated (O) and PTU-fed $(O)$ rats.

Each point represents a mean value.

The standard error of mean is indicated by vertical bars.

Ordinate : percent changes of contractile amplitude relative to those existing prior to addition of methoxamine.

Abscissa : molar concentrations of methoxamine on a logarithmic scale. 


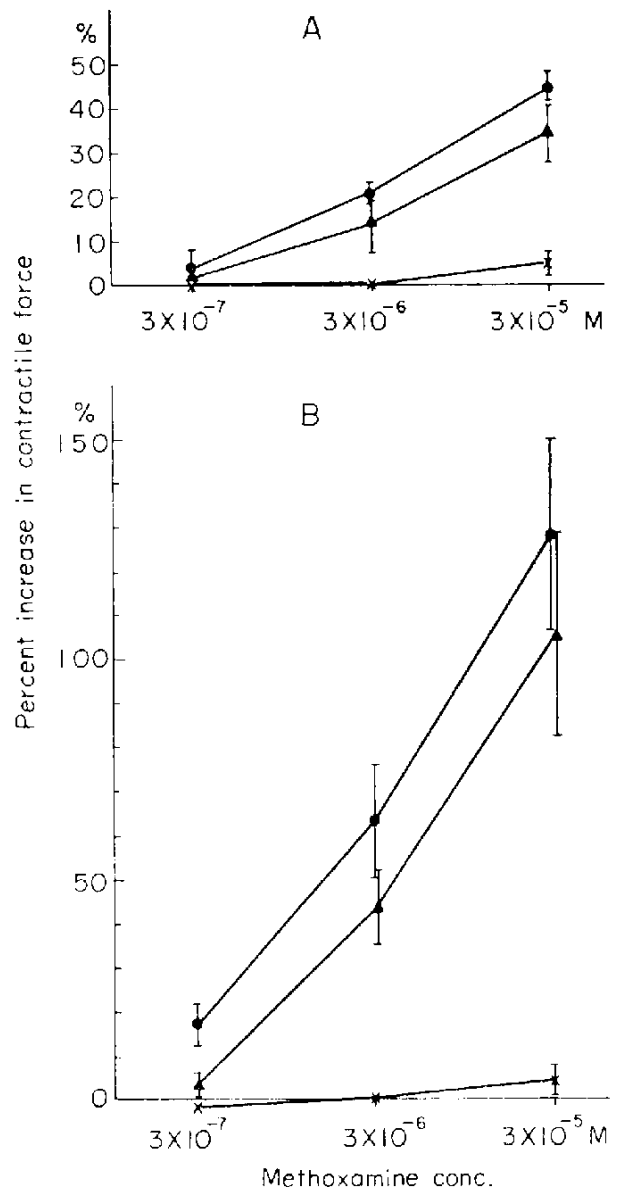

Fic. 2. Effects of propranolol and phentolamine on dose response curves for the inotropic action of methoxamine in non-treated (A) and PTU-fed (B) rats.

- methoxamine alone

A methoxamine after propranolol $3 \times 10^{-7} \mathrm{M}$

$\times$ methoxamine after phentolamine $3 \times 10^{-7} \mathrm{M}$

appeared to be diminished by propranolol, but the difference between control and propranolol pretreatment groups was not statistically significant (Fig. 2A, B). Fig. 3 depicts a typical example of these responses. The numbers of non-treated and PTU-fed rats used for these experiments were 5 and 13 respectively.

Fig. 4 shows the dose response curves for the chronotropic action of methoxamine in non-treated and PTU-fed rats. Absolute increase in spontancously beating rate in PTU-fed rat was greater than that observed in non-treated rats $(P<0.05)$. These dose response curves were blocked by $3 \times 10^{-7} \mathrm{M}$ phentolamine but not by $3 \times 10^{-7} \mathrm{M}$ propranolol (Fig. 5). The numbers of non-treated and PTU-fed rats used for these experiments were 8 and 17 respectively. 

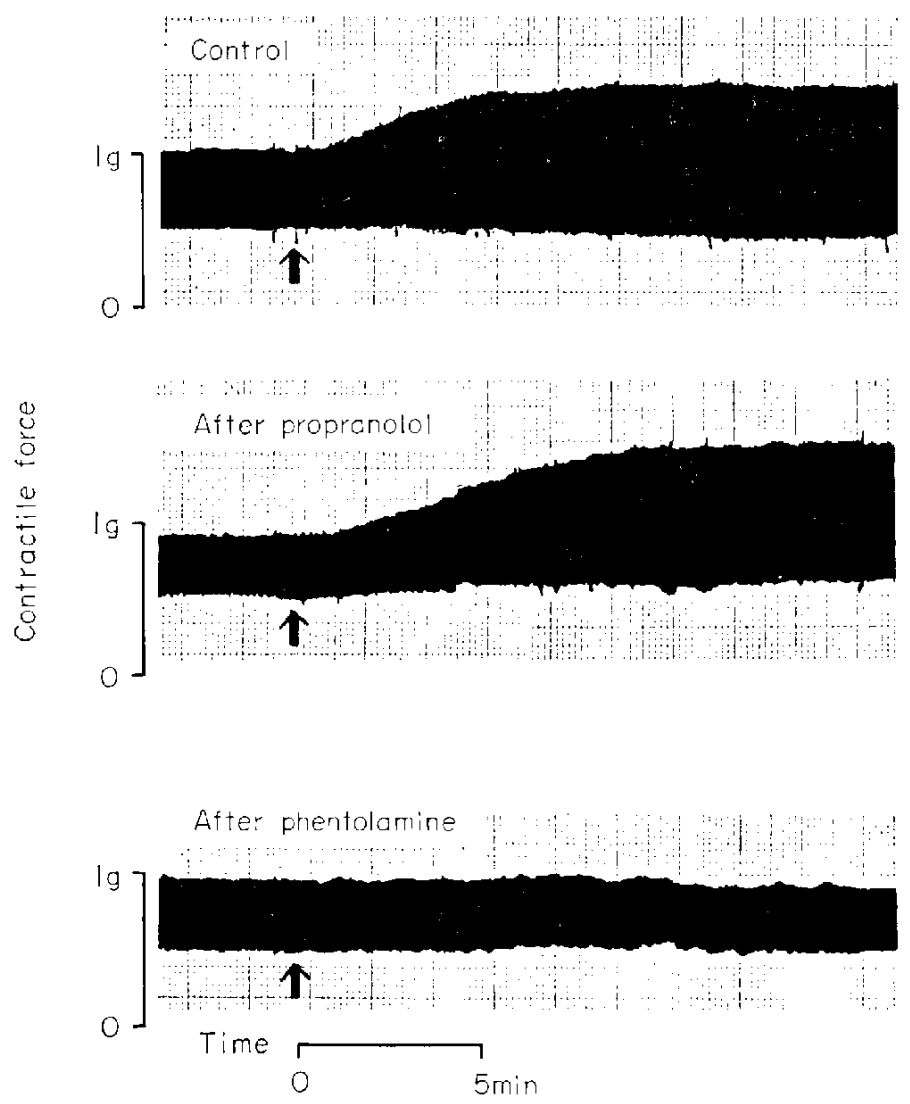

FiG. 3. Effects of $3 \times 10^{-7} \mathrm{M}$ propranolol or $3 \times 10^{-7} \mathrm{M}$ phentolamine on the positive inotropic action of $3 \times 10^{-5} \mathrm{M}$ methoxamine in PTU-fed rats.

Methoxamine was added at the point indicated by arrows.

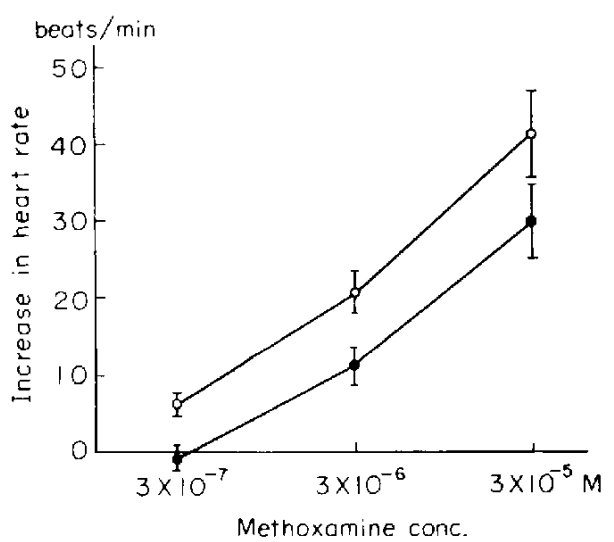

FiG. 4. Influence of graded doses of methoxamine on spontaneously beating rate in atria from non-treated $(\mathbf{O})$ and PTU-fed (O) rats.

Ordinate : absolute change of spontaneously beating rate. 


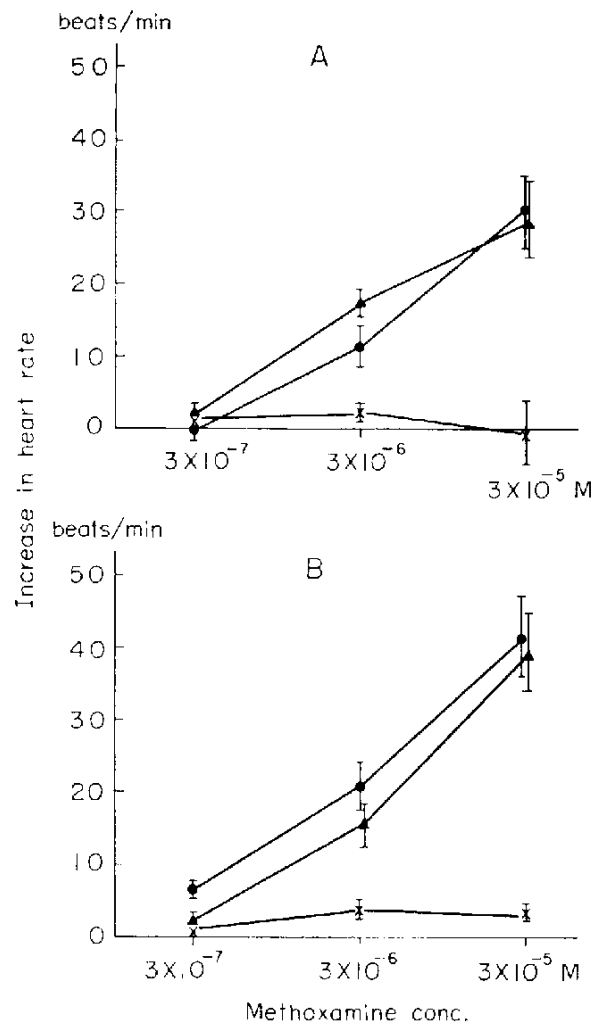

Fici. 5. Effects of propranolol and phentolamine on dose response curves for the chronotropic action of methoxamine in non-treated (A) and PTU-fed (B) rats.

- methoxamine alone

A methoxamine after propranolol $3 \times 10^{-7} \mathrm{M}$

$\times$ methoxamine after phentolamine $3 \times 10^{-7} \mathrm{M}$

\section{DISCUSSION]}

Many investigators (3-8) have reported that methoxamine, as one of pure $\alpha$ stimulants, has virtually no cardio-stimulant action. Methoxamine has also $\beta$ blocking property, so that larger doses of methoxamine often produce negative inotropic and chronotropic responses in the mammalian heart $(5,7,8)$.

In the present experiment, however, methoxamine showed positive inotropic and chronotropic actions in the rat atria. Bo1h of these actions were blocked by phentolamine, but not by propranolol. Release of catecholamine from the heart was ruled out, since these actions of methoxamine were not depressed by reserpine pretreatment (unpublished observation). In previous experiments $(1,2)$, it was observed that phenylephine exerts both positive inotropic and chronotropic actions on the rat atria, which are produced by stimulation of both $\alpha$ and $\beta$ receptors. The present results support these previous suggestions that there are $\alpha$ receptors in the heart and stimulation of the $\alpha$ receptors produces positive inotropic and chronotropic effects.

It has been demonstrated that there are both $\alpha$ and $\beta$ receptors in the hearts of 
rabbit $(9,10)$, guinea pig $(11)$, rat $(12,13)$ and frog $(13)$ and that stimulation of the $\alpha$ receptors produces a positive inotropic response. Participation of $\alpha$ receptors in chronotropic response to phenylephrine, however, has been ruled out by some authors $(10,14)$. James et al. (8), reported that $\alpha$ receptor stimulation produces negative chronotropic action in dogs. For these reasons it is of interest that the experiments herein clearly showed the involvement of $\alpha$ receptor in the positive chronotropic response to phenylephrine and methoxamine in the rat atria.

In both previous $(1,2)$, and present experiments, it was also observed that positive inotropic and chronotropic responses mediated by $\alpha$ adrenergic receptor were potentiated after PTU treatment. Such a treatment may provide a useful method for the experimental analysis of the $\alpha$ adrencrgic mechanism.

\section{REFERENCES}

1) Nakashima, M., Maeda, K., Sekiya, A. and Hagino, Y.: Japan. J. Pharmacol. 21, 819 (1971)

2) Nakashima, M. and Hagrio, Y.: Japan. J. Pharmacal. 22, 227 (1972)

3) Melville, E.I. And Lu, F.C.: Archs int. Pharmacodyn. Therr. 92, 108 (1952)

4) Aviado, D.M. and Wnuck, A.L.: J. Pharmacol. exp. Ther. 119, 99 (1957)

5) Imal, S., Sulger, T. and Hashimoto, K.: Circulation Res. 9, 552 (1961)

6) Stormorken H., De Schaepdryver A.F. and De Vleeschhouwer, G.R.: Archs int. Pharmacodyn. Thér. 120, 386 (1959)

7) Preziosi, P., De Vleeschhouwer, G.R., De Schaepdryyer, A.F. and Blanchi, A.: Archs int. Pharmacodyn. Thér. 121, 506 (1959)

8) Jamfs, T.N., Bear, E.S., Lang, K.F. and Green, E.W.: Am. J. Physiol. 215, 1366 (1968)

9) Benily, B.G. and Varma, D.R.: Br. J. Pharmacol. Chemother. 30, 603 (1967)

10) Parr, J.J. ANd URquilla P.R.: Eilropean J. Pharmacol. 17, 1 (1972)

11) Govier, W.C., Mosal, N.C., Whitungton, P. and Broom, A.H.: J. Pharmacol. exp. Ther. 154,255 (1966)

12) Wenzli, D.G. and Su, J.L.: Archs int. Pharmacodyn. Thér. 160, 379 (1966)

13) Kunos, G. A.vd Szentivayyl, M.: Nature, Lond, 217, 1077 (1968)

14) Krell, R.D. and Patil, P.N.: J. Pharmacol. exp. Ther. 170, 262 (1969) 